research and development for each skilled man is just under $\$ 50,000$. All this seems to be in line with the tendency for the industrial companies which have traditionally made the least use of scientists and engineers to increase the numbers so employed and to spend more on them, and for the companies at the other end of the scale to economize somewhat, both on numbers and costs.

\section{More Militant Doctors}

HARD on the heels of the young hospital doctors another section of the medical profession has been stung to militancy by the effects of the pay freeze in Britain. This time it is the turn of the medical teachers, whose Association of University Clinical Academic Staff was set up on November 12. They have been caught by the freeze in a very awkward position, and it looks as if the Government intends them to stay that way. The position of clinical teachers has been anomalous ever since the National Health Service was set up. Their pay is somewhere between that of non-medical university teachers and that of their equivalents in the N.H.S. Since 1963, however, the N.H.S. doctors have had two rises, the second of which is substantial and comes into force in January. Nonmedical university teachers have also had a rise recently. The medical teachers have had nothing. By January, the difference between the pay of a clinical senior lecturer and an N.H.S. consultant at the equivalent level could be as much as $£ 1,500$. But the teachers are also restricted because they cannot earn money by private practice. Repeated representations on their behalf by the British Medical Association, and lately by the Association of University Teachers, have been met blankly by the Government, which now talks of referring the claims to the Prices and Incomes Boarda procedure which would certainly mean a long delay and in the present economic climate might well mean they would end up with nothing.

This is the background to what Dr. Ian Bouchier, secretary of the new association, describes as a great deal of unrest. He emphasizes that the new body is not a breakaway from the B.M.A. and the A.U.T., although some clinical teachers have shown impatience with both bodies. Dr. Bouchier is worried that some of his members will not continue indefinitely with constitutional methods-there have already been underground murmurings about strike action. The full effects of the increased discrepancy in salaries will not come out into the open until well into 1967 , but many clinical teachers may leave at the end of the academic year-70 per cent in London are said to be thinking seriously about leaving teaching. It seems clear that if the Government wants more doctors to be trained, it must be prepared to pay the price.

\section{Accident, Trauma and Shock}

Accidental injuries are the "neglected disease of modern society" according to the Committees on Trauma and Shock of the U.S. National Academy of Sciences-National Research Council. Their pamphlet Accidental Death and Disability (Washington, D.C., September 1966) paints a grim picture of the haphazard organization of accident services in the United States. Fifty-two million people were injured in accidents in the United States during 1965, ten million seriously. More than one hundred thousand of these died, making accidents the fourth largest killer and the chief cause of deaths in the first four decades of life. As the report points out, however, the chances of survival from a serious wound are better in Vietnam than on the average city street. The committees criticize the inadequacy of much of the present machinery for preventing and treating accidents. Most hospital casualty departments are little more than first aid posts, woefully ill-equipped to deal with anything serious. Even the largest hospitals often lack the emergency facilities to give the best possible care to seriously injured patients. Municipal and state authorities have frequently neglected their responsibility to provide suitable and co-ordinated ambulance services - as many as half the accident cases are carried in undertakers' hearses, which act as spare time ambulances. In fact the report can state that "No manu. facturer produces from the assembly line a vehicle that can be termed an ambulance". The sums spent in research in the field are negligible, only about $\$ 5$ million being spent on accident research in 1963 , compared with about $\$ 120$ million spent on cancer research in the same period. Relatively few people have training in first aid.

The committees recommend a sweeping reform in the field of accidents: all children should get first aid instruction at school; minimum standards should be set for emergency services; money should be poured into a crash programme of research. They recommend setting up a National Institute of Trauma under the U.S. Public Health Service to co-ordinate research into wounds and accidents. They call for a National Council on Accident Prevention and a National Trauma. Association, and for more use of helicopters to fly patients to hospitals. This comprehensive but brief report deserves to be acted on.

\section{Division of Responsibility}

Some indecision is evident in the annual report of the Chemical Research Laboratory of the Ccmmonwealth Scientific and Industrial Research Organization (C.S.I.R.O., Melbourne, Australia). The laboratory is sited at Fishermen's Bend, and is very overcrowded; as long ago as 1958 a new site was obtained at Clayton, near Monash University, with the intention of moving the whole laboratory to the new site. So far, however, only one of the six divisions has moved to Clayton. Meanwhile, another new site has been obtained near Fishermen's Bend, and during the year the Division of Mineral Chemistry moved to this site. The fact that the committee of the laboratory felt compelled to express its concern at these developments, in a report which is otherwise notable for how little it gives away, indicates that feelings run high. The committee feels that the division of the laboratory into three parts throws away the advantages of economies of scale and easy collaboration which are the justification of large laboratories.

The expenditure of the laboratory in the current year amounts to $\$ 2,348,450$ ( $£ 940,000$ ), which represents a large proportion of the total C.S.I.R.O. expenditure on chemical research. Other laboratories, such as the Protein Chemistry Division, spend a further $\$ 1.7 \mathrm{~m}$ on work which can be broadly classified as chemistry, so that the total figure is probably about $\$ 4 \mathrm{~m}(£ 1.6 \mathrm{~m})$. (The grants awarded by the United Kingdom Science Research Council in the same 